\title{
USING ANALYTIC HIERARCHY PROCESS (AHP) FOR TOURIST DESTINATION CHOICE: A CASE STUDY OF CROATIA
}

\author{
Ivana Blešić \\ Tatjana Pivac \\ Maja Lena Lopatny
}

https://doi.org//10.20867/tosee.06.7

\begin{abstract}
Purpose - Understanding how and why people travel, decide and select a specific place, and what they expect from their destination to meet their actual needs is also a highly important topic. The goal of this article is to investigate the elements that influence Serbian visitors' decision to visit Croatia (Cratian coastline) as a destination. The most important characteristics, components, and types of tourism destinations are analysed. The definition of consumer behavior is explained, as well as the idiosyncrasies of the decision-making process. The most important internal and environmental elements that influence tourist decision-making are summarized. An examination of the cultural, societal, and personal psychological aspects that influence decision-making of Serbian tourists to travel to Croatian cost with different attributes like see, cultural and natural attractions, image, price, human resources is done.

Methodology - As a result, the decision-making process is extremely difficult, particularly when determining which factors are more significant than others. The Analytical Hierarchical Process (AHP) method, which has a strong mathematical foundation, could be used to find a good solution to this problem. The Analytical-hierarchy process (AHP) is a systematic way to solving complicated problems that leverages hierarchical structures by generating priorities for various options decided by decision makers.

AHP can aid tourism decision-making by examining a large number of decision factors (e.g., factors influencing destination choice, motives for visiting a place, hotel site selection, tourist indicators) and measuring the relevance of each component impacting the decision. The questionnaire used for this manuscript was taken from the paper Blešić et al. (2018). The questionnaire consist of five factors that include 22 items.

Findings - Destination amenities, tourism infrastructure, cultural attractions, human resources, price, environmental features are the importnant attributes for choosing Croatian coast as tourism destination.

Contribution - this study makes a valuable contribution by highlighting tourists' motives for visiting coastline destinations in Croatia. Finally, understanding the motivations and preferences of tourists is critical to realizing the full potential of tourism. Consumer behavior research is crucial for tourism sector stakeholders because it can provide important insights into who the tourist is and how stakeholders (travel agencies, hotels, restaurants, food producers, cultural organizations, and so on) can target and develop markets successfully. This research will help researchers better understand what inspires Serbian tourists to visit a Croatian coastal location. The findings will indicate the most common travel motivations that lead Serbian travelers to choose Croatia as their vacation location.
\end{abstract}

Keywords: decision-making, tourism destination, Croatia coastline, Serbian tourist, AHP method. 
ToSEE - Tourism in Southern and Eastern Europe, Vol. 6, pp. 95-107, 2021.

I. Blešić, T. Pivac, M.L. Lopatny: USING ANALYTIC HIERARCHY PROCESS (AHP)

\section{INTRODUCTION}

Tourism represents one of the most significant sectors for the growth and advancement of any country's economy. During the last fifty years, activities related to tourism have grown rapidly and the number of tourists is increasing every year (Gilandeh et al. 2017; Ilban and Yildirim 2017).

The ability of a tourist destination to fulfil the needs and preferences of tourists is the factor which determines whether it would be successful or not. Tourists want to travel to new places, to get acquainted with new people, seek out new friendships or deepen existing ones, seek out new experiences and information, seek rest and relaxation, seek out leisure activities (Mahika 2011; Simková and Holzner 2014; Wong et al. 2013). The section of a tourist destination where they choose to spend their time away from home can be a single place or a collection of areas (Jafari 2000). But one of the most important questions is according to which criteria tourists choose their destination? The most common selection rule is to enhance the utility of tourists. Also, tourists ordinarily selected a destination consistent with their expectations. Distinct expectations are based on completely different aspects of various destinations (Pizam and Mansfeld 1999). When thinking about a destination tourists decide according to their ideas and beliefs. According to some authors the most important factor is the general impression of the destination "in the decision of where tourist will travel". General impression is commonly thought about to be "more vital than reality" as image within the mind of tourists affects the planning process of their next vacation (El Kadhi 2008). Some of the image of destination characteristics are: architecture and buildings, historical monuments, museums, the landscape and natural sites, the climate, the sports facilities or activities, beach, shopping, accommodation, the level of prices, exhibitions held in cities, festivals, quality of roads, airports and harbors, hospitality and friendliness of local people, poverty, quality of life, language barriers and others (Echtner and Ritchie1991; Beerli and Martin 2004; Rajesh 2013).

Croatia is presently one of the most important and fastest growing tourism destinations in the world. During its summer months, Croatia offers a traditional "sea and sun" tourism model, with stays concentrated in coastal districts. Croatia has been a popular tourist destination for a long period of time due to its convenient location and natural charms (European Commision 2018).

\section{COASTLINE TRAVEL MOTIVATION AND DECISION-MAKING}

Elements which influence tourists' decision which destination to visit are various: factors, such as social, personal, cultural, and psychological, the amount of tourist attractions, price, human resources, out-of-the-way facilities, and a variety of tourism locations are all factors to consider. Numerous researches analysed various aspects of consumer decision-making and behaviour (Hawkins et al. 1995; Hsu et al. 2009; Baker and Crompton 2000; Moutinho 2005; Sirakaya and Woodside 2005; Chen and Chen 2010; Al-Tarawneh 2012; Schiffman et al. 2014; Seyidov and Adomaitiene 2016). The process of recognizing and selecting among viable solutions to a problem based on the demands of the situation is known as decision-making (Al-Tarawneh 2012). The 
ToSEE - Tourism in Southern and Eastern Europe, Vol. 6, pp. 95-107, 2021.

I. Blešić, T. Pivac, M.L. Lopatny: USING ANALYTIC HIERARCHY PROCESS (AHP)

decision-making process of a tourist can be a sophisticated, multi-faceted process impacted by a variety of internal and external influences. Consumer behaviour factors make it easier to figure out what items and services individuals use in different situations (Seyidov and Adomaitiene 2016). Selecting the right destination for tourism is an important decision-making process to ensure that it will meet tourists' needs and satisfaction. Tourists' decision-making behaviour is a compound procedure, powerfully influenced by the attributes and characteristics of a destination, in addition as past experiences (Shukla et al. 2006; Ansah 2014).

Many authors have analyzed tourism motivation (Crawford and Godbey 1987; Crompton 1979; Dann 1981; Jackson 2000; Mayo and Jarvis 1981; Pearce 1982; 1991; 2005; Pearce and Caltabiano, 1983) and is still a popular research topic (Božić et al. 2016; Božić et al. 2017a; Božić et al. 2017b; Huang et al. 2001; Jang et al. 2002; Jiang 2015; Leong et al. 2015; Lesjak et al. 2015; Li et al. 2015; Wong and Tang 2016). The most noted theoretical ideas that are applied to measure travel motivation are Maslow's hierarchy of needs, Alderfer's Existence, Relatedness and Growth (ERG) theory, Herzberg's motivator-hygiene theory (Ghazi et al. 2010) moreover as push-pull theory, Iso-Ahola's escape seeking duality (1982) and the travel career ladder (TCL) theory (Pearce 1988). All the above ideas agree on one thing: psychological and/or biological demands drive people to travel. Motivation is the desire to fulfil a desire that drives someone to act in a certain way. For a variety of reasons and incentives, people are motivated to travel. Though a range of psychological factors influence the decision to satisfy requests, human conduct may be related to an incentive (Correia et al. 2007). What, on the other hand, motivates a visitor to travel? Tourists are compelled to depart their daily routine in search of fresh experiences, according to anthropology (Yoon and Uysal 2003). The links between tourists' motivation and behaviour have rarely been explored, according to Cohen et al. (2013). Most of the research focus on motivation alone, neglecting how motivation is created. Tourism motivation encompasses a wide spectrum of human behaviours and experiences. Tourist motivation can include rest and relaxation, recreation, socialization with friends, outdoor activities, and an escape from daily life. The four categories with the most traveller benefits are the following: natural incentives linked to physical relaxation and rest, as well as sports activities, cultural incentives linked to people's desire to travel to other countries and learn about their cultures, interpersonal incentives linked to people's desire to visit relatives or friends, and finally incentives that influence people's standing and prestige and are linked to selfesteem and personal development needs (Bhatia 2006; Pantouvakis and Patsiouras 2016).

Coasts are attractive for tourists because they offer some unique characteristics. The coast has been a popular travel destination, prompting studies on what motivates people to visit and how to define break travel. Coastal tourism is becoming more harmful for the breakable natural and cultural areas, as those areas are mostly preferred by the tourists (Ghosh 2011) and it is one of the most rapidly expanding sectors of the world's largest industry. Concept "Sun, sea and sand" was a dominant motive for selecting coastline country as Croatia as a tourism destination, while natural beauties were the second dominant motive (Težak et al. 2010) 
ToSEE - Tourism in Southern and Eastern Europe, Vol. 6, pp. 95-107, 2021.

I. Blešić, T. Pivac, M.L. Lopatny: USING ANALYTIC HIERARCHY PROCESS (AHP) ...

\section{COAST OF CROATIA AS A TOURIST DESTINATION}

In recent years, Croatia has been an unavoidable tourist destination for many travellers from all over the world. What do they all see in that country and why has it become so popular? There are many reasons.

The Croatian coast is adorned with a Mediterranean climate which is perfect for a summer vacation. The country has a very good traffic connection, with many kilometres of good highways. One of the reasons why Croatia has become a hit among tourists is its untouched nature. Apart from the fact that there are eight national parks in the country, which are located on the coast or a few hours' drive from it, there are also numerous nature parks and protected areas. The sea is very clean in the whole country, as well as the beaches.

The Adriatic Sea and Croatia's shoreline have the most tourism potential. The crystal clear and pure ocean, as well as the comparatively sparsely populated shoreline (the coastline is over $1,800 \mathrm{~km}$ long, with over 1,000 islands, just 66 of which are inhabited), are well-known landmarks that are regarded as the most important comparative advantage of Croatian tourism (Blešić et al. 2018). According to the Croatian Tourist organization, the most successful destination of Croatian tourism for holiday tourism in 2019 was Rovinj, and in 2018 it was Mali Losinj (Croatian Tourism Board, n.d.).

Croatian income from tourism has participated with almost $20 \%$ in total GDP in recent years. For tourism, 2019 was the best year so far, with almost 21 million of tourist arrivals and 108.6 million of tourist overnights. Total tourism revenues exceeded 9.5 billion euros. In recent years, Croatia's tourism development plan has attempted to awaken Serbian tourists' nostalgy and other forgotten memories about Croatian islands and beaches. Over the years, the number of Serbian tourists has constantly increased, particularly on the Croatian Adriatic (Pivac et al. 2016). The data show that the number of Serbian tourists in Croatia has been growing. In 2019, there were 151,295 of Serbian tourists, or $10 \%$ more than the year before, and they made 630,237 overnight stays, i.e., an average of 4.2 days. However, this official data should be accepted with a grain of salt because a huge part of guests from Serbia spend their summer holidays with relatives, friends or are owners of houses where they stay during the summer period (Vreme 2020).

\section{METHODOLOGY}

Decision-making on the choice of tourist destination requires a combination of several criteria and alternatives that are complex and interconnected. Saaty (1980) established the analytical-hierarchy process (AHP), which is a systematic approach. Because the decision maker breaks down the complex problem of decision-making into multiple decision-making aspects amongst which he/she constructs a hierarchy, the process is "analytical" and "hierarchical" The phrase "process" in the name of the method suggests that after the formation of the preliminary hierarchy of decision problems, its iterative adjustments are allowed (Saaty 1990). The hierarchy of decision problems has quite a few levels, with the goal at the top of the hierarchy; the next level contains $n$ criteria, while at the bottom there are $\mathrm{m}$ alternatives. This hierarchical setting refers to the 
ToSEE - Tourism in Southern and Eastern Europe, Vol. 6, pp. 95-107, 2021.

I. Blešić, T. Pivac, M.L. Lopatny: USING ANALYTIC HIERARCHY PROCESS (AHP)

standard problem of decision-making, but there are also cases when the hierarchy has four or more levels. Then among the criteria and the alternatives we have the level of the sub-criteria, which is the case in this research. After the formation of the hierarchy, the decision maker compares the factors in pairs at the given level of the hierarchy in relation to all the factors at a higher level, to determine their mutual significance. In the standard AHP, the elements are compared by using giving linguistic (semantic) assessments of their mutual significance in relation to the aspect at a higher level of the hierarchy using the basic scale from Table 1 (Saaty 1980).

Every comparison of the two elements of the hierarchy (model) is done by using the Satie scale given in Table 1 . To determine the values of the vectors of weight coefficients, it is necessary to form appropriate comparison matrices by entering the results of comparison of elements at a given level of the hierarchy (Saaty 1992).

Table 1: Saaty's importance scale

\begin{tabular}{ll}
\hline $\begin{array}{l}\text { Intensity of importance on an } \\
\text { absolute scale }\end{array}$ & Definition \\
\hline 1 & Equal importance \\
3 & Moderate importance of one over another \\
5 & Essential or strong importance \\
7 & Very strong importance \\
9 & Extreme importance \\
$2,4,6,8$ & Intermediate values between the two adjacent judgments \\
\hline
\end{tabular}

Source: Saaty (1980)

After determination, the vector of weight coefficient is multiplied by the higher-level element weight coefficient used as a comparison criterion. The technique is repeated as the hierarchy's levels are reduced. The so-called composite relative weight coefficients of elements at lower levels are determined by calculating weight coefficients for each element at a given stage. At the end of the procedure, composite weighting coefficients of all alternatives are determined. Their sum is equal to 1 . The relative relevance of each choice in respect to the goal at the top of the hierarchy, as well as the determined order of alternatives by importance, are the most essential pieces of information available to the decision maker at the conclusion of the method. If the degree of consistency (CR) is less than 0.10 , the result is adequately accurate. If the degree of consistency is greater than 0.10 , the results should be corrected by partially repeating the comparison in pairs or repeating the whole procedure from the beginning, to bring the degree of consistency to the tolerance limit of 0.10 (Karlsson 1998).

\section{QUESTIONNAIRE DESIGN AND STUDY SAMPLE}

The questionnaire used for this research was taken from the paper of Blešić et al. (2018). The authors conducted a survey on a sample of 850 tourists from Serbia who visited destinations in Croatia at least once. The factor analysis revealed a five-component solution with 22 items, according to the findings (Table 3 ). 
ToSEE - Tourism in Southern and Eastern Europe, Vol. 6, pp. 95-107, 2021.

I. Blešić, T. Pivac, M.L. Lopatny: USING ANALYTIC HIERARCHY PROCESS (AHP) ...

Five factors (criteria) and 22 items (sub-criteria) were applied to define the key criteria and sub-criteria for selection of a tourist destination in Croatia by employees in tourism sector (travel agencies and tourism organizations in Serbia), as well as experts in the field of tourism, professors from the Department of Geography, Tourism and Hotel Management, Faculty of Science in Novi Sad. In the research participated only respondents who visited the five most attractive destinations in Croatia at least once, selected on the basis of the research of Blešić et al. (2018).

Destinations Pula, Rovinj, Umag, Mali Lošinj and Poreč presented alternatives as the five most desirable destinations on the Croatian coast according to the attitudes of tourists from Serbia (Table 2).

Figure 1 shows the problem's hierarchical structure, which is the focus of this research.

Table 2: Favorite tourist destinations in Croatia

\begin{tabular}{lrr}
\hline Destination & Frequency & $\%$ \\
\hline Pula & $\mathbf{1 6 7}$ & $\mathbf{1 9 , 6}$ \\
Rovinj & $\mathbf{1 8 9}$ & $\mathbf{2 2 , 2}$ \\
Umag & $\mathbf{1 4 3}$ & $\mathbf{1 6 , 8}$ \\
Mali Lošinj & $\mathbf{1 1 8}$ & $\mathbf{1 3 , 9}$ \\
Korčula & 6 &, 7 \\
Brač & 9 & 1,1 \\
Hvar & 13 & 1,5 \\
Dubrovnik & 14 & 1,6 \\
Split & 10 & 1,2 \\
Zadar & 6 &, 7 \\
Poreč & 104 & 12,2 \\
Rijeka & 71 & 8,4 \\
\hline Total & 850 & 100,0 \\
\hline
\end{tabular}

Source: Blešić et al. (2018)

The survey was sent out electronically to the e-mail addresses of 19 travel agencies, 7 travel organizations and 15 employees at the Faculty of Science, DGTH. A sample of 26 correctly completed survey questionnaires was obtained. The sampling approach for the The AHP technique can be employed with a carefully selected purposive sample that is well-suited to collecting qualitative data, making it appropriate for research that focuses on a single topic and does not necessitate a large sample size (Cheng and Li 2002). Smallsample groups of two to five persons are defined as small-sample groups in AHP, while large-sample groups of more than five people are characterized as large-sample groups (Ossadnik et al. 2016). 
ToSEE - Tourism in Southern and Eastern Europe, Vol. 6, pp. 95-107, 2021.

I. Blešić, T. Pivac, M.L. Lopatny: USING ANALYTIC HIERARCHY PROCESS (AHP) ...

Figure 1: Hierarchical structure of the problem

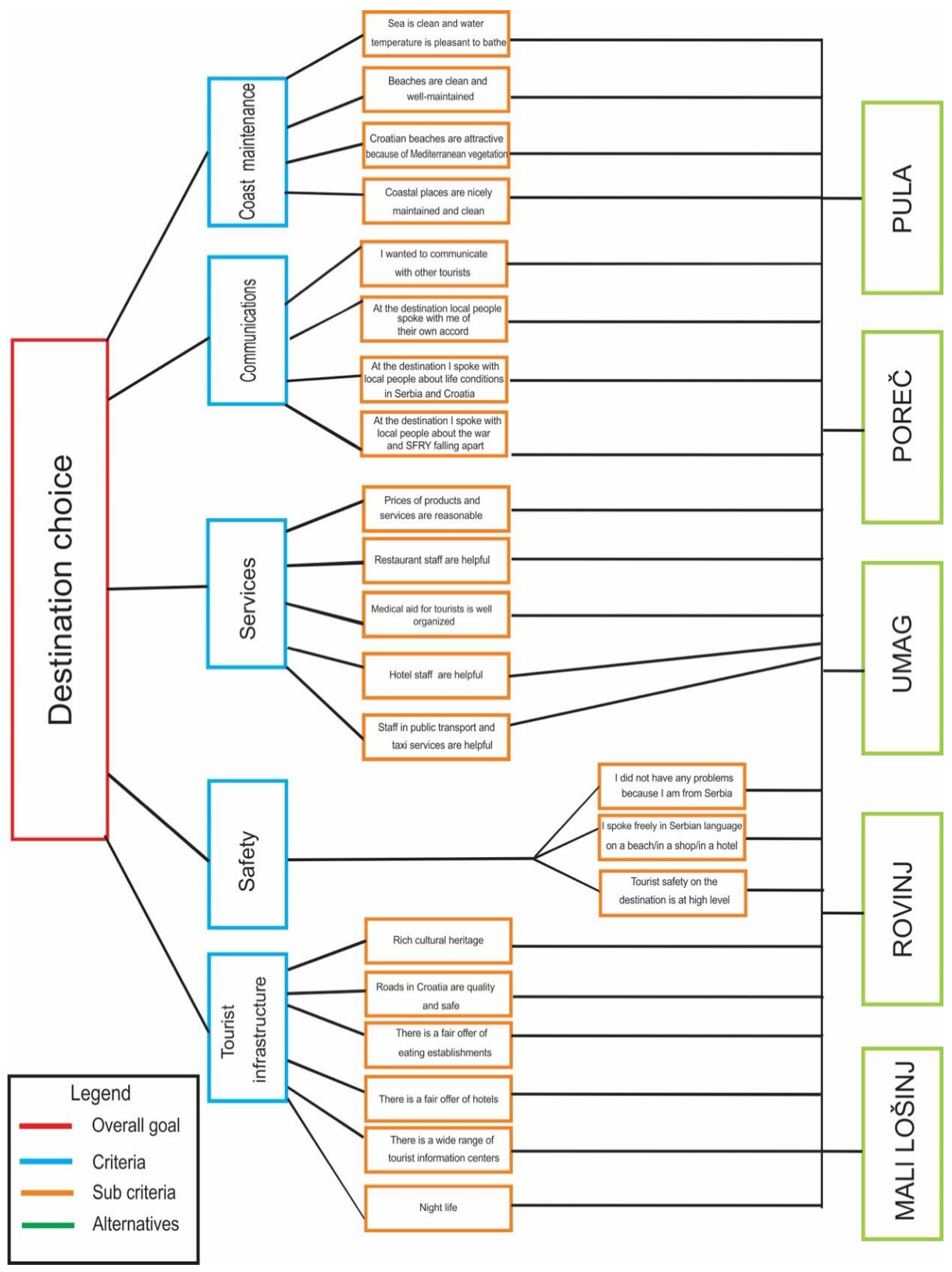

Source Authors' research 
ToSEE - Tourism in Southern and Eastern Europe, Vol. 6, pp. 95-107, 2021.

I. Blešić, T. Pivac, M.L. Lopatny: USING ANALYTIC HIERARCHY PROCESS (AHP) ...

\section{RESULTS}

Coast maintenance $(0.321)$, followed by communications $(0.211)$, services $(0.202)$, and safety $(0.199)$ are the most important characteristics influencing the choice of coastline destination in Croatia at the first level of the hierarchy, whereas tourist infrastructure is the least important (0.68). The consistency ratio (CR) is 0.01 , indicating that the study is dependable and accurate and that the weight criteria do not need to be re-evaluated. On the second level of the hierarchy, the combined replies of the respondents produce an analysis of all sub-criteria, and the weight coefficients obtained recommend the most dominant to the least dominant in terms of sub-criteria influencing the criterion for choosing a seaside destination (Table 3 ).

\section{Table 3: Individual and total weight values for criteria and sub-criteria}

\begin{tabular}{|c|c|}
\hline Factors (criteria) & Items (sub-criteria) \\
\hline Coast maintenance $(0.321)$ & $\begin{array}{l}\text { The sea is clean, and the water temperature is comfortable for } \\
\text { bathing (0.501) } \\
\text { The beaches are clean and well-kept }(\mathbf{0 . 2 0 3 )} \\
\text { Because of the beautiful Mediterranean vegetation, Croatian } \\
\text { beaches are appealing } \mathbf{( 0 . 2 0 1 )} \\
\text { Coastal areas are well-kept and spotless (0.091) }\end{array}$ \\
\hline Communications $(0.211)$ & $\begin{array}{l}\text { I wanted to interact with other visitors }(0.052) \\
\text { Locals at the destination spoke with me on their own initiative } \\
(\mathbf{0 . 2 5 6 )} \\
\text { I spoke with locals about living in Serbia and Croatia when I } \\
\text { arrived at the destination }(\mathbf{0 . 2 2 0}) \\
\text { I chatted with locals about the conflict and the disintegration } \\
\text { of the SFRY when I arrived at my location }(\mathbf{0 . 0 6 8 )}\end{array}$ \\
\hline Services $(0.202)$ & $\begin{array}{l}\text { Product and service prices are reasonable }(0.286) \\
\text { Restaurant staff are helpful }(\mathbf{0 . 2 5 3 )} \\
\text { Tourist medical assistance is well-organized }(\mathbf{0 . 2 0 8 )} \\
\text { The hotel staff is friendly and accommodating (0.109) } \\
\text { The people who work in public transportation and taxi } \\
\text { services are friendly and helpful (0.080) }\end{array}$ \\
\hline Safety (0.199) & $\begin{array}{l}\text { I did not have any problems because I am from Serbia }(0.414) \\
\text { I spoke freely in Serbian language on a beach/in a shop/in a } \\
\text { hotel (0.352) } \\
\text { The destination's tourist safety is excellent } \mathbf{( 0 . 2 3 4 )}\end{array}$ \\
\hline Tourist infrastructure $(0.68)$ & $\begin{array}{l}\text { Rich cultural heritage }(0.267) \\
\text { Croatian roads are of good quality and are well-maintained } \\
(\mathbf{0 . 2 6 6 )} \\
\text { There is a good selection of restaurants to choose from } \\
(\mathbf{0 . 2 6 3 )} \\
\text { There is a good selection of hotels }(\mathbf{0 . 0 9 1 )} \\
\text { There are numerous tourist information centers to choose } \\
\text { from }(\mathbf{0 . 0 6 0 )} \\
\text { Night life }(\mathbf{0 . 0 5 2})\end{array}$ \\
\hline & \\
\hline
\end{tabular}

Source: data analysed in Expert Choice 2000 program 
ToSEE - Tourism in Southern and Eastern Europe, Vol. 6, pp. 95-107, 2021.

I. Blešić, T. Pivac, M.L. Lopatny: USING ANALYTIC HIERARCHY PROCESS (AHP)

Figure 2 presents the overall weights or priority in the selection of coastline destination in this study. Based on Figure 2, the results show that Mali Lošinj (0.282) is the most preferred destination between the Serbian tourists, followed by Rovinj (0.274), Umag (0.158), Poreč (0.153) and Pula (0.132).

Figure 2: Total weight values for the alternatives (coastline destinations)

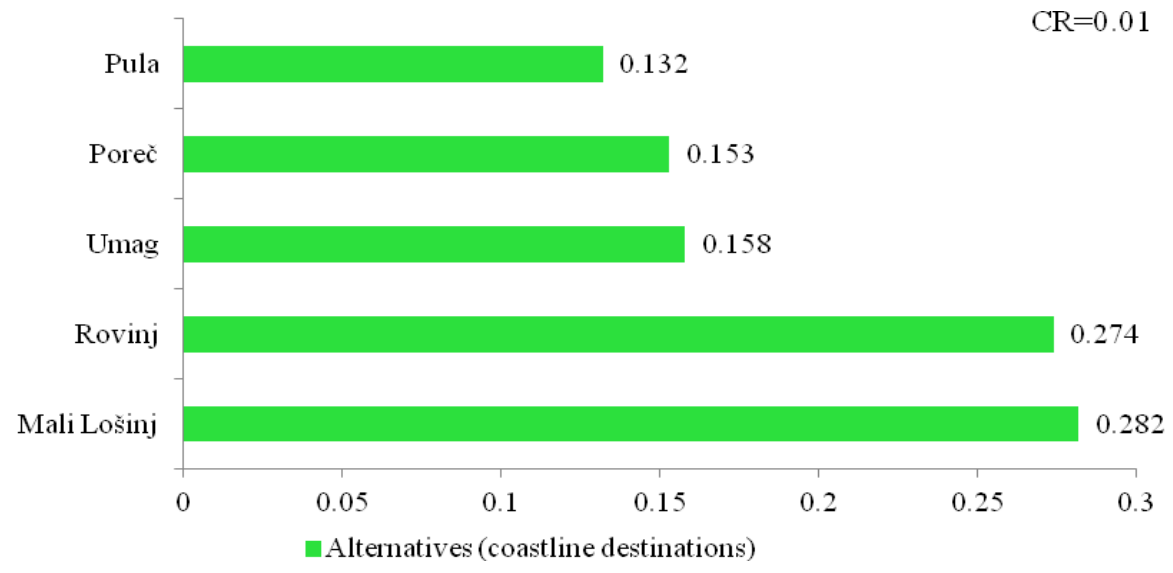

Source Authors' research

\section{DISCUSSION AND CONCLUSION}

According to the findings, coast upkeep is the most important factor in deciding whether to visit Croatia's coastal tourism areas, followed by communications, and finally tourist infrastructure. Individual items at the lowest level of the hierarchy (sub criteria) describe the Croatian coast as a very attractive destination for tourists from Serbia. The most dominant factor was the cleanness and temperature of the sea water (Sea is clean and water temperature is pleasant to bathe). Also, among the individual factors, those related to the feeling of security and safety of tourists stand out (I did not have any problems because I am from Serbia).

This finding complements already established destination image of Istria and PrimorjeGorski Kotar County, which are recognizable by attractive coastal towns, crystal clear sea water and lush Mediterranean vegetation, but also by the hospitable local population and employees in tourism and hotel management (Pivac et al. 2016; Blešić et al. 2018). Other research have also shown that the cleanness and temperature of seawater, as well as the natural characteristics of sea shores, are important motivators for visiting coastal destinations. As a result, according to Hall (2001), coastal tourism is a type of tourism in which the water element is the most essential and is seen as the destination's principal asset and benefit. 
ToSEE - Tourism in Southern and Eastern Europe, Vol. 6, pp. 95-107, 2021.

I. Blešić, T. Pivac, M.L. Lopatny: USING ANALYTIC HIERARCHY PROCESS (AHP) ...

The lowest ranked factors suggest that visitors to the Croatian coast are not primarily motivated by social factors such as meeting and communicating with other tourists, as well as "nightlife", i.e., visiting bars and nightclubs.

To achieve the goals, AHP model was constructed with evaluation aim, standards, and criteria weights, and comparison locations (Pula, Rovinj, Umag, Mali Lošinj i Poreč) in a hierarchy.

The results have shown that the most desirable destination is Mali Losinj, followed by Rovinj and Umag. These results coincide with the data of the Croatian Tourist Board, where Rovinj and Mali Lošinj were chosen as the most successful Croatian tourism destinations for holiday tourism in 2019 and 2018 (Croatian Tourist Board, n.d.).

The implementation of the AHP approach for measuring motivation to travel in Croatia's coastal tourism attractions is the study's key contribution. The hierarchy of elements that influence visitors to Croatia's coastal tourism sites provides significant information for destination management and marketing.

Future research will be focused on different sample of visitors, which will provide a more accurate insight into the factors that motivate and demotivate tourists and it will help marketing experts to adapt the tourist offer and to make a better placement of coastal destinations on the market in Serbia.

\section{ACKNOWLEDGEMENTS}

"The authors acknowledge financial support of the Ministry of Education, Science and Technological Development of the Republic of Serbia (Grant No. 451-03-9/2021-14/ 200125)"

\section{REFERENCES}

Al-Tarawneh, H.A. (2012), "The main factors beyond decision making", Journal of Management Research Vol. 4, No. 1, pp. 1-23. https://doi.org/10.5296/jmr.v4i1.1184

Ansah, G.O. (2015), "Choice: Motivational Factors Among Social Science Students' Associations At KNUST", Researchjournali's Journal of Hospitality Tourism, Vol. 2, No. 1, pp.1-11.

Baker, D.A. and Crompton, J.L. (2000), "Quality, Satisfaction and Behavioral Intentions", Annals of Tourism Research, Vol. 27, No. 3, pp. 785-804. https://doi.org/10.1016/S0160-7383(99)00108-5

Beerli, A. and Martin, J.D. (2004), "Factors influencing destination image", Annas of Tourism Research, Vol. 31, No. 3, pp. 657-681. https://doi.org/10.1016/j.annals.2004.01.010

Bhatia, A. (2006), The Business of Tourism: Concepts and Strategies, Sterling Publishers Private Limited, New Delhi.

Blešić, I., Pivac, T., and Besermenji, S. (2018), "Croatia as a tourist destination from the perspective of tourists from Serbia", Megatrend revija, Vol. 15, No. 1, pp. 19-34. doi: 10.5937/MegRev1801019B

Božić, S., Jovanović, T., Tomić, N. and Vasiljević, D.A. (2017b), "An analytical scale for domestic tourism motivation and constraints at multi-attraction destinations: The case study of Serbia's Lower and Middle Danube region", Tourism Management Perspectives, Vol. 23, pp. 97-111. doi: 10.1016/j.tmp.2017.05.002

Božić, S., Kennell, J., Vujičić, M.D. and Jovanović, T. (2017a), "Urban tourist motivations: why visit Ljubljana?", International Journal of Tourism Cities, Vol. 3, No. 4, pp. 382-398. https://doi.org/10.1108/IJTC-03-2017-0012

Božić, S., Spasojević, B., Vujičić, M.D. and Stamenkovic, I. (2016), "Exploring the motives for religious travel by applying the AHP method: a case study of Vujan Monastery (Serbia)", International Journal of Religious Tourism and Pilgrimage, Vol. 4, No. 4, pp. 33-47. 
ToSEE - Tourism in Southern and Eastern Europe, Vol. 6, pp. 95-107, 2021.

I. Blešić, T. Pivac, M.L. Lopatny: USING ANALYTIC HIERARCHY PROCESS (AHP) ...

Chen, C.F. and Chen, F.S. (2010), "Experience quality, perceived value, satisfaction and behavioral intentions for heritage tourists", Tourism management, Vol. 31, No. 1, pp. 29-35. https://doi.org/10.1016/j.tourman.2009.02.008

Cheng, E.W. and Li, H. (2002), "Construction partnering process and associated critical success factors: quantitative investigation", Journal of management in engineering, Vol. 18, No. 4, pp. 194-202. https://doi.org/10.1061/(ASCE)0742-597X(2002)18:4(194)

Cohen, S., Prayag, G., and Moital, M. (2014), "Consumer behaviour in tourism:Concepts, influences and opportunities", Current Issues in Tourism, Vol. 17, No. 10, pp. 872-909. https://doi.org/10.1080/13683500.2013.850064

Correia, A., Oom do Valle, P. and Moco, C. (2007), "Why people travel to exotic places", International Journal of Culture, Tourism and Hospitality Research, Vol. 1, No. 1, pp. 45-61. https://doi.org/10.1108/17506180710729600

Crawford, D.W. and Godbey, G. (1987), "Reconceptualizing barriers to family leisure", Leisure Sciences, Vol 9, No. 2, pp. 119-127. https://doi.org/10.1080/01490408709512151

Croatian Tourist Board n.d., Destination of the year, viewed 28 April 2021, https://www.htz.hr/hr-HR/projektii-potpore/godisnje-hrvatske-turisticke-nagrade/destinacija-godine

Crompton, J.L. (1979), "Motivations for pleasure vacation", Annals of Tourism Research, Vol. 6, No. 4, pp. 408-424. https://doi.org/10.1016/0160-7383(79)90004-5

Dann, G. (1981), "Tourism Motivation: An Appraisal", Annals of Tourism Research, Vol. 8, No. 2, pp. 187219. https://doi.org/10.1016/0160-7383(81)90082-7

Echtner, C.M. and Ritchie, B.J.R. (1991), "The meaning and measurement of destination image", Journal of tourism studies, Vol. 2, No. 2, pp. 2-12.

El Kadhi, W. (2008), Destination Image-Do Berlin's tourist authorities have to consider cultural segmentation when developing marketing strategies relating to the place's image in an era that refers to the global tourist?, Druck Diplomica, Hamburg.

European Commission Directorate-General for Economic and Financial Affairs 2018, Croatia's Tourism Industry: Beyond the Sun and Sea, viewed 21 April 2021, https://ec.europa.eu/info/sites/default/files/economy-finance/eb036_en.pdf

Ghazi, S.R., Ali, R., Khan, M.S., Hussain, S. and Fatima, Z.T. (2010), "Causes of the Decline of Education in Pakistan and Its Remedies", Journal of College Teaching \& Learning (TLC), Vol. 7, No. 8, pp. 918. https://doi.org/10.19030/tlc.v7i8.139

Ghosh, T. (2011), "Coastal Tourism: Opportunity and Sustainability", Journal of Sustainable Development, Vol. 4, No. 6, pp. 67-71. http://dx.doi.org/10.5539/jsd.v4n6p67

Gilandeh, A.G., Silabi, P.D. and Ghadimi, M. (2017), "Ranking tourism attractions based on potential to attract tourists by using Numerical Taxonomy Model (Case: City of Khoy) ", Journal of Urban Economics and Management, Vol. 5, No. 4, pp. 119-132. https://doi.org/10.29252/iueam.5.20.113

Hall, C.M. (2001), "Trends in ocean and coastal tourism: The end of the last frontier? ", Ocean and Coastal Management, Vol. 44, No. 9-10, pp. 601-618. https://doi.org/10.1016/S0964-5691(01)00071-0

Hawkins, D.I., Best, R. G. and Coney, K.A. 1995, Consumer behavior: Implications for marketing strategy, 6th ed., viewed 21 February 2021, https://openlibrary.org/books/OL1104922M/Consumer_behavior

Heung, V.C.S., Qu, H. and Chu, R. (2001), "The relationship between vacation factors and socio demographic and traveling characteristics: the case of Japanese leisure travellers", Tourism Management, Vol. 22, No. 3, pp. 259-269. doi: 10.1016/S0261-5177(00)00057-1

Hsu, T.K., Tsai, Y.F. and Wu, H.H. (2009), "The preference analysis for tourist choice of destination: A case study of Taiwan", Tourism Management, Vol. 30, No. 2, pp. 288-297. doi: 10.1016/j.tourman.2008.07.011

Ilban, M.O. and Yildirim, H.H. (2017), "Determination of tourism activities of the world's best tourism destinations using the Multi-Criteria Decision-Making method", Cogent Social Sciences, Vol. 3 , No. 1, pp. 1-16. https://doi.org/10.1080/23311886.2017.1301763

Iso-Ahola, S.E. (1982), "Toward A Social Psychological Theory of Tourism Motivation: A Rejoinder", Annals of Tourism Research, Vol. 9, No. 2, pp. 256-262. https://doi.org/10.1016/0160-7383(82)90049-4

Jackson, E.L. (2000), "Will research on leisure constraints still be relevant in the twenty-first century? " Journal of Leisure Research, Vol. 32, No. 1, pp. 62-68. doi: 10.1080/00222216.2000.11949887

Jang, S.C., Morrison, A.M. and O’Leary, J.T. (2002), "Benefit Segmentation of Japanese Pleasure Travelers to the USA and Canada Selecting Target Markets Based on the Profitability and Risk of Individua Market Segments", Tourism Management, Vol. 23, No. 4, pp. 367-378. https://doi.org/10.1016/S0261-5177(01)00096-6

Jiang, S. (2015), "Using means-end chain theory to explore travel motivation, pp. An examination of Chinese outbound tourists", Journal of Vacation Marketing, Vol. 21, No. 1, pp. 87-100. doi: $10.1177 / 1356766714535599$ 
ToSEE - Tourism in Southern and Eastern Europe, Vol. 6, pp. 95-107, 2021.

I. Blešić, T. Pivac, M.L. Lopatny: USING ANALYTIC HIERARCHY PROCESS (AHP) ...

Karlsson J.A. (1998), Systematic Approach for Prioritizing Software Requirements (Doctoral dissertation), Linköping University, Department of Computer and Information Science, The Institute of Technology, Linköping.

Leong A.M.W., Yeh S.S., Hsia Y.C. and Huan T.C.T.C. (2015), "Nostalgia as travel motivation and its impact on tourists' loyalty", Journal of Business Research, Vol. 68, No. 1, pp. 81-86. https://doi.org/10.1016/j.jbusres.2014.05.003

Lesjak, M., Juvan, E., Ineson, E.M., Yap, M.H.T. and Podovšovnik, E. (2015), "Erasmus student motivation, why and where to go?", Higher education, Vol. 70, No. 5, pp. 845-865. https://doi.org/10.1007/s10734015-9871-0

Li, H., Pearce, P.L. and Zhou, L. (2015), "Documenting Chinese tourists' motivation patterns", in Wilson, E. and Witsel, M. (Eds.), CAUTHE 2015: Rising Tides and Sea Changes, Adaptation and Innovation in Tourism and Hospitality Education Conference: rising tides and sea changes, 2-5 February 2015, Gold Coast, QLD, Australia, pp. 235-246.

Mahika, E. (2011), "Current trends in tourist motivation", Cactus Tourism Journal, Vol. 2, No. 2, pp. $15-24$.

Mayo, E. and Jarvis, L.P. (1981), The Psychology of Leisure Travel: Effective Marketing and Selling of Travel Services, CBI Publishing Company Inc., Boston.

Moutinho, L. (2005), Strategic management in Tourism, CABI Publishing, Cambridge.

Ossadnik, W., Schinke, S. and Kaspar, R.H. (2016), "Group aggregation techniques for analytic hierarchy process and analytic network process: a comparative analysis", Group Decision and Negotiation, Vol. 25, No. 2, pp. 421-457. doi: 10.1007/s10726-015-9448-4

Pantouvakis, A., Patsiouras, C. (2016), "Tourists' Selection Criteria and Motivation. Does Nationality Matter? " SPOUDAI Journal of Economics and Business, Vol. 66, No. 1-2, pp. 22-31.

Pearce, P.L. (1982), "The social psychology of tourist behavior", Pergamon Press, New York.

Pearce, P.L. (1988), "The Ulysses Factor: Evaluating Visitors in Tourist Settings", Verlag-Springer, New York.

Pearce, P.L. (1991), "Fundamentals of Tourist Motivation", in Pearce, D.G. and Butler, R.W. (Eds.), Fundamentals of Tourism Motivation, Routledge, London, pp. 113-134.

Pearce, P.L. (2005), Tourism Behaviour: Themes and Conceptual Schemes, Channel View, Clevedon, UK

Pearce, P.L. and Caltabiano, M.L. (1983), "Inferring Travel Motivation from Traveler's Experiences", Journal of Travel Research, Vol. 22, No. 2, pp. 16-20. https://doi.org/10.1177/004728758302200203

Pivac, T., Blešić, I., Stamenković, I., Ivanović, L. and Penić, M. (2016), "The Image of Croation as a Tourist Destination Impression of Serbian Tourists", Tourism Education Studies and Practice, Vol. 8, No. 2, pp. 63-71. doi: 10.13187/tesp.2016.8.63

Pizam, A. and Mansfeld, Y. (1999), "Cosnumer Behavior in Travel and Tourism". The Haworth Hospitality Press, Binghamton.

Rajesh, R. (2013), "Impact of tourist perceptions, destination image and tourist satisfaction on destination loyalty: A conceptual model", PASOS. Revista de Turismo y Patrimonio Cultural, Vol. 11, No. 3 , 67-78. doi: 10.25145/j.pasos.2013.11.039

Saaty, T.L. (1990), "How to make a decision: the analytic hierarchy process", European journal of operational research, Vol. 48, No. 1, pp. 9-26. https://doi.org/10.1016/0377-2217(90)90057-I

Saaty, T. L. (1992), "Decision Making for Leaders: The Analytic Hierarchy Process for Decisions in a Complex World", RWS Publications, Pittsburgh

Saaty, T.L. (1980), "The analytic hierarchy process", McGraw-Hill Inc, New York.

Schiffman, L., O’Cass, A., Paladino, A. and Carlson, J. (2014), Consumer Behaviour, 6th ed., viewed 21 March 2021,

https://books.google.ru/books?id=VDXiBAAAQBAJ\&printsec=frontcover\&hl=ru\#v=onepage \&q $\& \mathrm{f}=$ false

Seyidov, J. and Adomaitienè, R. (2016), "Factors Influencing Local Tourists’ Decision-Making on Choosing a Destination: a Case of Azerbaijan", Ekonomika, Vol. 95, No. 3, pp. 112-127. https://doi.org/10.15388/Ekon.2016.3.1033

Simková, E. and Holzner, J. (2014), "Motivation of Tourism Participants", Procedia - Social and Behavioral Sciences, Vol. 159, pp. 660-664. https://doi.org/10.1016/j.sbspro.2014.12.455

Sirakaya, E. and Woodside, A. G. (2005), "Building and testing theories of decision making bymtravellers", Tourism Management, Vol. 26, No. 6, pp. 815-832. doi: 10.1016/j.tourman.2004.05.004

Težak, A., Šergo, Z. and Luk, N. (2010), "Impact of Economic Crisis on Motivations for Selecting a Tourist Destination", in Proceedings of 20th Biennial International Congress Tourism \& Hospitality Industry 2010, May 6-8, 2010, pp. 202-212, Opatija, Croatia.

Vreme 2020, Kontrolirani hrvatski turizam, viewed 28 April 2021, https://www.vreme.com/cms/view.php?id=1786666

Wong, K.K.F. and Tang S.W. (2016), "Linking Travel Motivation and Loyalty in Sporting Events: The Mediating Roles of Event Involvement and Experience, and the Moderating Role of Spectator 
ToSEE - Tourism in Southern and Eastern Europe, Vol. 6, pp. 95-107, 2021.

I. Blešić, T. Pivac, M.L. Lopatny: USING ANALYTIC HIERARCHY PROCESS (AHP) ...

Type", Journal of Travel and Tourism Marketing, Vol. 33, No. 1, pp. 63-84. https://doi.org/10.1080/10548408.2015.1038417

Wong, M., Cheung, R. and Wan, C. (2013), "A Study on Traveler Expectation, Motivation and Attitude", Contemporary Management Research, Vol. 9, No. 2, pp. 169-186. https://doi.org/10.7903/cmr.11023

Yoon, Y. and Uysal, M. (2003), "An examination of effects of motivation and satisafction on destination loyalty: a structural model", Tourism Management, Vol. 26, No. 1, pp. 45-56. doi: 10.1016/j.tourman.2003.08.016

Ivana Blešić, PhD, Full Professor

${ }^{1}$ University of Novi Sad, Faculty of Sciences

Department of Geography, Tourism and Hotel Management

Trg Dositeja Obradovića 3

21000 Novi Sad, Serbia;

${ }^{2}$ South Ural State University, Institute of Sports, Tourism and Service

76 Lenin Ave., 454080 Chelyabinsk, Russia

+381638842756

ivana.blesic@dgt.uns.ac.rs

Tatjana Pivac, PhD, Full Professor

University of Novi Sad, Faculty of Sciences,

Department of Geography, Tourism and Hotel Management

Trg Dositeja Obradovića 3

21000 Novi Sad, Serbia

+381641759344

tatjana.pivac@dgt.uns.ac.rs

Maja Lena Lopatny, PhD Student

Faculty of Tourism and Hospitality Management,

Opatija

lopatny1@gmail.com 